\title{
The Earnings Quality Consequences of Announcements to Voluntarily Adopt the Fair Value Method of Accounting for Stock-Based Compensation
}

\author{
Shilpa Manaktala, John D. Phillips, and Karen Teitel
}

October 2004

\section{COLLEGE OF THE HOLY CROSS, DEPARTMENT OF ECONOMICS \\ FACULTY RESEARCH SERIES, WORKING PAPER NO. 04-13*}

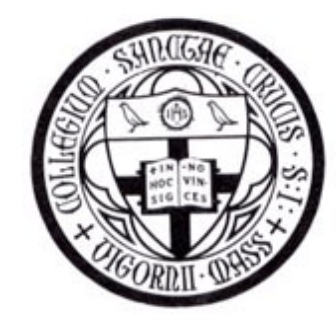

Department of Economics

College of the Holy Cross

Box 45A

Worcester, Massachusetts 01610

(508) 793-3362 (phone)

(508) 793-3710 (fax)

http://www.holycross.edu/departments/economics/website

*All papers in the Holy Cross Working Paper Series should be considered draft versions subject to future revision. Comments and suggestions are welcome. 


\title{
The Earnings Quality Consequences of Announcements to Voluntarily Adopt the Fair Value Method of Accounting for Stock-Based Compensation
}

\author{
Shilpa Manaktala ${ }^{\dagger}$ \\ University of Connecticut
}

\author{
John D. Phillips ${ }^{\dagger+}$ \\ University of Connecticut
}

\author{
and \\ Karen Teitel ${ }^{\dagger+\dagger}$ \\ College of the Holy Cross
}

October 2004

\begin{abstract}
We identify 133 firms that between July and December 2002, announced plans to voluntarily adopt the fair value method of accounting for stock-based compensation. We investigate whether such announcements increased the quality of these firms' earnings as perceived by market participants. Answering this research question not only provides evidence relevant to the debate surrounding the expensing of employee stock options, but doing so provides evidence that conservative accounting choices in general lead to higher perceived earnings quality. Using two measures of earnings quality, the price-earnings relation and the earnings response coefficient, we find evidence consistent with an increase in perceived earnings quality for these firms relative to a control set of firms that in 2002 did not announce plans to adopt the SFAS 123 stock-based compensation recognition provisions.
\end{abstract}

\section{JEL Classification Codes:}

Keywords: SFAS, stock options, accounting, expensing options, fair value method

We would like to thank Rick Tubbs, Stan Veliotis, Mike Willenborg, and workshop participants at the University of Connecticut for their helpful suggestions. The financial support of the University of Connecticut School of Business is greatly appreciated.

${ }^{\dagger}$ Shilpa Manaktala, University of Connecticut, School of Business

${ }^{+}$John D. Phillips, University of Connecticut, School of Business, 2100 Hillside Road Unit 1041, Storrs, CT 06269-1041, 860-486-2789 (phone), john.phillips@business.uconn.edu

${ }^{\mathrm{H}+\mathrm{H}}$ Karen Teitel, Department of Economics, Box 157A, College of the Holy Cross, Worcester, MA 01610-2395, 508-793-2649 (phone), 508-793-3710 (fax), kteitel@holycross.edu 


\title{
The Earnings Quality Consequences of Announcements to Voluntarily Adopt the Fair Value Method of Accounting for Stock-Based Compensation
}

\author{
Tentative and Preliminary \\ Please do not quote without permission
}

\section{Introduction}

We identify 133 firms (hereinafter referred to as "recognizing firms") that between July and December, 2002, announced plans to voluntarily adopt the fair value method of accounting for stock-based compensation. ${ }^{1}$ The purpose of this study is to examine the impact of such announcements on the recognizing firms' earnings quality. Specifically, we investigate whether announcements to adopt the fair value method increased the recognizing firms' earnings quality as perceived by market participants. We also investigate whether firms that had previously used the fair value method to value executive stock option grants disclosed in proxy statements experienced a greater increase in perceived earnings quality relative to firms that had not used the fair value method for proxy statement disclosure purposes.

Accounting for employee stock options (ESOs) has sparked considerable debate in recent years. APB 25 (APB, 1973) generally requires firms to record ESO expense only if the market value of the stock on the grant date exceeds the exercise price. Because ESOs typically have an exercise price at least equal to the stock price on the date of grant, and thus no intrinsic value, firms typically report little or no APB 25 ESO expense. In 1993, the Financial Accounting Standards Board (FASB) issued an exposure draft (FASB, 1993), which required firms to value ESOs at the grant date using a fair value method (e.g., Black-Scholes) and recognize ESO

\footnotetext{
${ }^{1}$ Our search resulted in a potential sample of 150 firms, but we eliminate from our study nine foreign firms, five firms with missing data, and three firms that switched yearends. Aboody, Barth, and Kasznik (2004a) identify 155 firms that announced plans to recognize ESO expense in 2002 and early 2003. 134 (21) of their sample firms made their announcements in 2002 (2003). We focus only on the 2002 announcers because we investigate the earnings quality of post-announcement earnings.
} 
expense over the options' vesting periods. In 1995, the FASB succumbed to considerable political pressure and in its final standard, SFAS 123, backed away from requiring firms to recognize ESO expense using the fair value method (FASB, 1995). Instead, SFAS 123 makes recognition of ESO expense using the fair value method optional and requires non-recognizing firms to disclose in the financial statement footnotes earnings per share amounts calculated as if the fair value method had been used. ${ }^{2}$

In 2002, the debate over ESO accounting resumed following a number of highlypublicized accounting scandals that were blamed, at least in part, on the incentives created by executive stock options (e.g., Becker, 2002). From July through December of 2002, the 133 recognizing firms announced that they would begin recognizing ESO expense according to the fair value method outlined in SFAS 123. Aboody, Barth and Kasznik (2004a) (hereinafter ABK) identify 155 firms that made such announcements in 2002 and early 2003 and found that the recognizing firms experienced positive abnormal returns around the announcement dates and argue that the voluntary adoption of SFAS 123 signals higher earnings quality. The positive stock price effects documented in ABK (2004a), however, are not a function of the recognizing firms' earnings. In this study, we investigate whether the recognizing firms' signals - the voluntary adoption of the fair value method of accounting for ESOs - enhanced their perceived earnings quality. We link the recognizing firms' positive stock price effects to their reported earnings and thus triangulate the findings in ABK (2004a).

We use the value relevance of earnings as a surrogate for earnings quality (e.g., Schipper and Vincent, 2003) and test whether the recognizing firms' value relevance of earnings,

\footnotetext{
${ }^{2}$ Aboody, Barth and Kasznik (2004a) report that only five publicly-traded firms chose to recognize ESO expense in the income statement prior to 2002. Accordingly, 133 firms announcing plans to do so represents a substantial increase in the number of firms recognizing ESO expense and suggests a fundamental change in the financial reporting environment.
} 
measured using both the price-earnings multiple and earnings response coefficient, are greater in the post-announcement period relative to the pre-announcement period. Importantly, we do not test whether the ESO expense recognition pursuant to SFAS 123 improves earnings quality. Rather, we test whether the announcements to recognize SFAS 123 ESO expense increased the recognizing firms' perceived earnings quality. Moreover, even though the evidence in ABK (2004a) suggests that the recognizing firms are fundamentally than the non-recognizing firms, our research design focuses on the recognizing firms' increases in perceived earnings quality and thus helps avoid selection bias issues.

Following Bagnoli and Watts (2004), we hypothesize that the impact of the announcements to voluntarily recognize SFAS 123 ESO expense on the recognizing firms' value relevance of earnings is increasing in the informativeness of the fair value method of accounting for ESOs. We assume that the fair value method is more (less) informative for firms that had (had not) previously valued executive stock option grants in their proxy statements using the fair value method. We argue that firms previously using the fair value method for proxy statement reporting purposes are able to send a more credible signal of earnings quality to market participants than those firms that had been not been using a fair value method for this purpose.

Our results are consistent with an increase in the recognizing firms' perceived earnings quality subsequent to their announcements to adopt the SFAS 123 recognition provisions. We find that the recognizing firms' price-earnings multiple and earnings response coefficient, relative to a control set of firms that did not announce plans to recognize ESO expense in 2002, increased significantly from the pre-announcement period to the post-announcement period. We do not find, however, an incremental increase in the value relevance of earnings associated with the prior use of the fair value method to value ESO grants disclosed in the recognizing firms' 
proxy statements. Overall, our results are consistent with the recognizing firms' announcements to voluntarily recognize ESO expense sending a credible signal of higher earnings quality to market participants.

Our study makes several contributions. First, we add to the stream of research that addresses voluntary accounting choices (see Fields, Lys and Vincent, 2001 for a review of this literature). Using value relevance as the surrogate for earnings quality (e.g., Ghosh and Moon, 2005), we investigate whether the recognizing firms' voluntary adoption of the fair value method of accounting for ESOs led to higher perceived quality of earnings. Second, our research also contributes to research that addresses disclosure versus recognition (e.g., Bernard and Schipper, 1994; Aboody, 1997; Barth, Clinch and Shibano, 2003; ABK, 2004b) because SFAS 123 requires disclosure of ESO expense and pro forma earnings per share when firms choose not to recognize ESO expense in the income statement. Third, we add to the literature that addresses the effects of conservative accounting choices (e.g., Ahmed et al., 2002). In contrast to prior studies that examine accruals which reverse over time, the choice to recognize ESO expense results in the persistent understatement of net income and thus provides a more powerful test of the consequences of conservative accounting choices. Finally, our study contributes to the stream of research addressing accounting for ESOs (e.g., Dechow, Hutton and Sloan, 1996; Espahbodi et al., 2002; ABK, 2004a; ABK, 2004b), a topic that is once again at the forefront of the FASB's agenda and the subject of considerable debate. We find that the announcements to voluntarily recognize ESO expense are not only value relevant but that earnings quality is enhanced. ABK (2004a) does not provide direct evidence that these announcements resulted in higher earnings quality. 
The paper proceeds as follows. The next section develops the hypotheses investigated in this study. The third section presents the models and data utilized to test the hypotheses. Section four provides the sample selection process, including the selection of a control group of firms that did not voluntarily announce plans to recognize SFAS 123 expense in 2002. Section five presents the results, and we conclude in section six.

\section{Hypothesis Development}

A key issue in the ongoing ESO accounting debate is whether mandating ESO expense recognition would improve earnings quality. Investigating whether announcements to voluntarily recognize ESO expense have increased the recognizing firms' perceived earnings quality will inform this debate. Evidence that market participants believe that such announcements enhance a firm's earnings quality would suggest to policymakers (e.g., the FASB, SEC, Congress) that they believe ESO expense recognition should be mandated for all firms.

The current ESO debate began in 2002 after several highly-publicized accounting scandals severely impacted investor confidence and reignited calls for corporate financial reporting reform. Placing a renewed emphasis on the importance of earnings quality, shareholders, other members of the investment community, and regulators began to demand increased transparency in corporate financial statements. In particular, the recent series of corporate failures highlighted a need for reform and increased conservatism with regard to the accounting rules for ESOs. For example, in an April, 2002 column written for the Washington Post, Berkshire Hathaway CEO, Warren Buffet states "Companies that expense options will develop a reputation for being believable, for not hyping things, and will be valued more than 
those whose CEO is flim-flamming [investors]" (Buffet, A19). ${ }^{3}$ During a May, 2002 Financial Markets Conference of the Federal Reserve Bank of Atlanta, Federal Reserve Board Chairman, Alan Greenspan, reiterated the need for enhanced transparency in financial statements and implicated the non-recognition of stock-based compensation as a contributing factor to the overall decline in earnings quality (Greenspan, 2002).

The press also reported estimates of the extent to which corporate earnings are overstated as a result of ESO expense (generally) not being recognized. For example, in a special report called "The Angry Market" published by Business Week, it was reported that U.S. companies had overstated earnings by approximately 15 percent due to the non-recognition of ESO expense and the underestimation of pension funding requirements (Henry, 2002). As evidence that ESO expensing would have a greater effect on larger companies, this special report estimates that if all firms in the S\&P 500 had expensed their ESOs, earnings per share would have declined by 24 percent in 2001 and by 17 percent in 2002 (Vickers, 2002).

Both the FASB and International Accounting Standards Board (IASB) responded to investor concerns and re-opened the stock option accounting debate. On February 19, 2004, the IASB issued International Financial Reporting Standard 2 Share-Based Payment, mandating the recognition of stock-based compensation expense using the fair value method (IASB, 2004). On March 31, 2004, after reviewing comment letters from the public and undergoing lengthy deliberations, the FASB issued Share-Based Payment, a proposed statement regarding the accounting rules for stock-based compensation (FASB, 2004). The proposed statement would eliminate the ability to account for ESO grants using the intrinsic value method under ABP 25,

\footnotetext{
${ }^{3}$ Indeed, six of the seven companies for which Buffet is a director have since elected to voluntarily adopt the fair value method of accounting for ESOs (ABK, 2004a).
} 
and would require firms to recognize stock-based compensation expense using the fair value method.

Consistent with the debate surrounding SFAS 123 a decade ago, the FASB's and IASB's actions have sparked heated debate. For example, Morgenson and Glater (2003) report that in its comment letter to the FASB, TechNet, an organization headquartered in the Silicon Value consisting of over 200 executives from companies in technology industries (e.g., software, biotech, e-commerce), argues that stock options are "something of value to employees" but asserted that the divergent views among accountants regarding the treatment of stock options as a "corporate expense" serves as evidence that the FASB should maintain the status quo. "We believe that requiring employee stock options to be treated as an expense would lead to misleading financial statements because no accurate, reliable and tested method of valuing stock options currently exists." ${ }^{4}$ Similarly, Congress is also weighing in on the stock option accounting debate. On July 20, 2004, the U.S. House of Representatives passed the Stock Option Accounting Reform Act (H.R. 3574), which impacts accounting for ESOs in several ways, the most important of which limits mandatory expensing of ESOs to options granted to the top executive and four other most highly paid executives. ${ }^{5}$

Two theoretical studies provide insights that a conservative accounting choice such as expensing ESOs serves as a signal of higher earnings quality. Hughes and Levine (2003) develop a signaling model in which there is an adverse selection problem between firms and their creditors. High quality firms are able to choose a conservative accounting method and still have earnings sufficient to avoid debt covenant violations and satisfy other accounting-based

\footnotetext{
${ }^{4}$ For more information on Technet see Who are we? 2004 Membership List. [Online] Retrieved March 5, 2004 from http://www.technet.org/who2/memberListName/

${ }^{5}$ H.R. 3574 also requires that, if a fair value method such as Black-Scholes is used to value ESOs, assumed volatility must be zero. This restriction would affect ESO values.
} 
contracts, whereas low quality firms are unable to mimic this strategy. The choice to recognize ESO expense using the fair value method is a conservative accounting method because doing so unambiguously results in lower net income.

Similarly, Bagnoli and Watts (2004) develop a signaling model in which managers trade off the stock price benefits of reporting conservatively versus the costs of potentially missing earnings expectations. They find a separating equilibrium in which "bad" firms report nonconservatively and "good" firms report conservatively. The intuition behind their result is that if the "bad" firm reports conservatively, mimicking "good" firms, the benefit of a higher stock price is outweighed by the costs of missing the firm's earnings expectation. In contrast, if the "good" firm reports non-conservatively, mimicking the "bad" firm, the benefit of beating the firm's earnings expectation is outweighed by the cost of a lower stock price.

Whereas Hughes and Levine (2003) and Bagnoli and Watts (2004) both provide theoretical support for the argument that a conservative accounting choice signals higher quality to financial statement users, the latter study also provides insights into the relation between earnings conservatism and stock prices. Generally, Bagnoli and Watts show that a firm's earnings response coefficient, a surrogate for earnings quality (Schipper and Vincent, 2003), is higher when it makes the conservative accounting choice.

Consistent with the signaling benefits of a conservative accounting choice, ABK (2004a) provide evidence that the 155 firms in their sample that announced plans to voluntarily recognize ESO expense did so to signal higher earnings quality and thus increase stock price. They find that firms more active in the capital market, firms with greater information asymmetry concerning the firms' prospects, firms with top managers having a greater incentive to increase stock prices, and larger firms with greater political costs were more likely to voluntarily adopt 
the SFAS 123 recognition provisions. Surprisingly, after controlling for other determinants, ABK (2004a) find that even though the magnitude of the effect of expensing ESOs on the recognizing firms' earnings was immaterial, it played an insignificant role in firms' decisions to announce plans to recognize ESO expense.

ABK (2004a) also indirectly test whether firms' announcements to voluntarily recognize ESO expense signaled higher earnings quality to market participants. ABK (2004a) argue that even though ESO expense is already disclosed in the footnotes, these announcements provide a credible signal of earnings quality that lowers information asymmetry between the firm and market participants. This reduced information asymmetry reduces the firm's risk premium, which, in turn, increases the firm's stock price (e.g., Bartov and Bodnar, 1996). Consistent with this argument, ABK (2004a) find that the recognizing firms experienced abnormal positive stock returns around the announcement dates. The positive stock market reactions to the recognizing firms' announcements, however, are not a function of earnings. Accordingly, to more directly investigate the earnings quality effects of these announcements, we test the following hypothesis (stated in the alternative):

H1: Recognizing firms have higher perceived earnings quality after the announcements of plans to voluntarily adopt the fair value method of accounting for ESOs than before the announcements.

At the heart of the ESO accounting debate is whether current valuation methods can be applied to ESOs (Morgenson and Glater, 2003). Since 1992, all publicly traded firms have had an opportunity to choose the fair value method to value ESO grants disclosed in their proxy statement filings. The 1992 proxy statement disclosure rules promulgated by the SEC give management limited discretion in reporting the value of stock options granted to top executives in the annual proxy statements. Firms can choose to report either the potential value of options 
granted assuming stock prices appreciate at 5 percent or 10 percent annually during the term of the option ("potential realizable value method"), or the present value of options on the date of grant estimated using the Black-Scholes model, a binomial model, or other accepted option pricing model. Accordingly, firms have historically made the choice of whether fair value methods are sufficiently reliable for their proxy statement ESO disclosures; i.e., firms that used the present value method presumably believe that method is more reliable and thus more informative than the potential realizable value method, and vice versa. We thus assume that the fair value method is more informative for the recognizing firms that had previously valued executive stock option grants in their proxy statements using the fair value method than for the recognizing firms that had used the potential realizable value method. We argue that firms previously using the fair value method for proxy statement reporting purposes are thus able to send a more credible signal of earnings quality to market participants. Accordingly, this discussion leads to our second hypothesis (stated in the alternative):

H2: Recognizing firms that use the present value method in their proxy statements will have a greater increase in perceived earnings quality than the recognizing firms that use the potential realizable value method in their proxy statements.

\section{Research Design}

In our investigation of the perceived earnings quality consequences of announcements to voluntarily adopt the fair value method of accounting for ESOs, we use two value relevance measures, the price-earnings multiple and the earnings response coefficient, as surrogates for earnings quality (Schipper and Vincent, 2003). We first model the price-earnings relation as follows:

$$
M V E_{i t}=\alpha_{0}+\alpha_{1} E_{i t}+\varepsilon_{i t}
$$

where 
$M V E_{i t}=$ market value of common equity three months after fiscal year end (monthly Compustat data item MKVALM) scaled by common shares outstanding (annual Compustat data item $\mathrm{CSHO}$ ) as of the beginning of the fiscal year;

$E_{i t} \quad=$ income before extraordinary items, discontinued operations, and changes in accounting principles (annual Compustat data item $I B$ ) scaled by the common shares outstanding (annual Compustat item $\mathrm{CSHO}$ ) as of the beginning of the fiscal year; and

$\varepsilon_{\mathrm{it}} \quad=$ random disturbance term.

We do not adjust the recognizing firms' post-announcement period earnings for recognized SFAS 123 ESO expense because we use income before changes in accounting principles as our earnings measure. Next, we revise equation (1) to separately estimate the priceearnings multiple both prior and subsequent to the recognizing firms' announcements to voluntarily adopt the recognition provisions of SFAS 123:

$$
M V E_{i t}=\alpha_{0}+\alpha_{1} E_{i t}+\alpha_{2} D P_{i}+\alpha_{3} E_{i t} * D P_{i}+\varepsilon_{i t}
$$

where

$D P_{i} \quad=$ an indicator variable equal to 1 for the first fiscal year ending after the announcement to adopt the fair value method was made; $D P_{i}$ equals 0 for the last fiscal year ending before the announcement; and all other variables are as previously defined.

Based on H1, we expect the increase in the price-earnings multiple from the preannouncement period to the post-announcement period, $\alpha_{3}$, to be positive. To control for the possibility that $\alpha_{3}$ simply captures a differential price-earnings multiple between years, however, and not the effect of announcements to voluntarily adopt the fair value method of accounting for 
ESOs, we identify a control set of firms that did not make such announcements and revise equation (2) as follows:

$$
\begin{aligned}
M V E_{i t}= & \alpha_{0}+\alpha_{1} E_{i t}+\alpha_{2} D P_{i}+\alpha_{3} E_{i t}{ }^{*} D P_{i}+\alpha_{4} D S_{i}+\alpha_{5} E_{i t} * D S_{i}+\alpha_{6} D P_{i} * D S_{i} \\
& +\alpha_{7} E_{i t}{ }^{*} D P_{i} * D S_{i}+\varepsilon_{i t}
\end{aligned}
$$

where

$D S_{i} \quad=$ an indicator variable equal to 1 if the firm announced the adoption of the fair value method in 2002; $D S_{i}$ equals 0 otherwise; and

all other variables are as previously defined. For the control firms, we set $\mathrm{DP}_{\mathrm{i}}=1$ for the first fiscal year ending after June, 2002 and $\mathrm{DP}_{\mathrm{i}}=0$ for the last fiscal year ending before July, $2002 .^{6}$

A positive coefficient on $E_{i t}{ }^{*} D P_{i} * D S_{i}, \alpha$, would be consistent with $\mathrm{H} 1$, and would be helpful in ruling out other events (e.g., the Sarbanes-Oxley legislation) as an explanation for the recognizing firms' increase in the price-earnings multiple.

Alternatively, we regress annual stock returns on earnings and the change in earnings to test $\mathrm{H} 1$ using the earnings response coefficient as a measure of earnings quality. Following Easton and Harris (1991), we begin by estimating the following model:

$$
R_{i t}=\beta_{0}+\beta_{1} E_{i t}+\beta_{2} \Delta E_{i t}+\mu_{\mathrm{it}}
$$

where

$$
\begin{aligned}
& R_{i t} \quad=\text { the market adjusted return using the equal-weighted market index for the } \\
& \text { twelve month period ending three months after fiscal year end; } \\
& E_{i t} \quad=\text { income before extraordinary items, discontinued operations, and changes in } \\
& \text { accounting principles (annual Compustat data item } I B \text { ) scaled by market value of }
\end{aligned}
$$

\footnotetext{
${ }^{6}$ In sensitivity tests in which we exclude control firms with July through November yearends, the inferences based on the results reported in Tables 3 and 4 do not change.
} 
equity at the end of the third month after year t-1 fiscal year end (monthly

Compustat data item MKVALM);

$\Delta E_{i t} \quad=$ the change in income before extraordinary items, discontinued operations, and changes in accounting principles from year t-1 (annual Compustat data item IB) scaled by market value of equity at the end of the third month after year t-2 fiscal year end (monthly Compustat data item $M K V A L M$ ); and

$\mu_{\mathrm{it}} \quad=$ random disturbance term.

Next, consistent with equation (2), we revise equation (4) to separately estimate the earnings response coefficient both prior and subsequent to the recognizing firms' announcements to voluntarily adopt the recognition provisions of SFAS 123:

$$
R_{i t}=\beta_{0}+\beta_{1} E_{i t}+\beta_{2} \Delta E_{i t}+\beta_{3} D P_{i}+\beta_{4} E_{i t} * D P_{i}+\beta_{5} \Delta E_{i t} * D P_{i}+\mu_{\mathrm{it}}
$$

where all variables are as previously defined. Positive coefficients on $E_{i t} * D P_{i}$ and $\Delta E_{i t} * D P_{i}, \beta_{4}$ and $\beta_{5}$, respectively, would be consistent with $\mathrm{H} 1$; i.e., the recognizing firms experience an increase in perceived earnings quality after the announcement to voluntarily adopt the fair value method of accounting for ESOs.

Consistent with equation (3), we also estimate the following model to compare the recognizing firms to the control set of firms that did not announce the intent to voluntarily adopt the SFAS 123 recognition provisions in 2002:

$$
\begin{aligned}
R_{i t}= & \beta_{0}+\beta_{1} E_{i t}+\beta_{2} \Delta E_{i t}+\beta_{3} D P_{i}+\beta_{4} E_{i t} * D P_{i}+\beta_{5} \Delta E_{i t} * D P_{i}+\beta_{6} D S_{i} \\
& +\beta_{7} E_{i t} * D S_{i}+\beta_{8} \Delta E_{i t} * D S_{i}+\beta_{9} D P_{i}^{*} D S_{i}+\beta_{10} E_{i t} * D P_{i} * D S_{i} \\
& +\beta_{11} \Delta E_{i t} * D P_{i} * D S_{i}+\mu_{\mathrm{it}}
\end{aligned}
$$

where all variables are as previously defined. We test whether $\beta_{10}>0$ and whether $\beta_{11}>0$; i.e., whether the recognizing firms' increases in earnings response coefficients are greater than the 
corresponding increases for the control firms. These results would be consistent with our first hypothesis (H1) that the recognizing firms experienced an increase in perceived earnings quality after the announcement to voluntarily recognize ESO expense according to SFAS 123.

To test our second hypothesis that recognizing firms using the present value method to value ESOs in their proxy statements experience a greater increase in perceived earnings quality than those firms using the potential realizable value method for this purpose, we modify equations (2) and (5) as follows:

$$
\begin{aligned}
M V E_{i t}= & \alpha_{0}+\alpha_{1} E_{i t}+\alpha_{2} D P_{i}+\alpha_{3} E_{i t} * D P_{i}+\alpha_{4} F V_{i}+\alpha_{5} E_{i t} * F V_{i}+\alpha_{6} D P_{i} * F V_{i} \\
& +\alpha_{7} E_{i t} * D P_{i} * F V_{i}+\varepsilon_{i t} \\
R_{i t}=\beta_{0}+ & \beta_{1} E_{i t}+\beta_{2} \Delta E_{i t}+\beta_{3} D P_{i}+\beta_{4} E_{i t} * D P_{i}+\beta_{5} \Delta E_{i t} * D P_{i}+\beta_{6} F V_{i}+\beta_{7} E_{i t} * F V_{i} \\
+ & \beta_{8} \Delta E_{i t} * F V_{i}+\beta_{9} D P_{i} * F V_{i}+\beta_{10} E_{i t} * D P_{i} * F V_{i}+\beta_{11} \Delta E_{i t} * D P_{i} * F V_{i}+\mu_{i t}
\end{aligned}
$$

where

$F V_{i}=$ an indicator variable equal to 1 if the company uses a fair value option pricing model to value ESO grants disclosed in its proxy statement (Black Scholes or binomial method); $F V_{i}$ equals 0 if the company uses an alternate option pricing model in its proxy statement; and

all other variables are as previously defined.

We test whether $\alpha_{7}>0$ in equation (7) and in equation (8) we test whether $\beta_{10}>0$ and whether $\beta_{11}>0$. These tests provide evidence regarding whether the recognizing firms that previously used the fair value method for proxy statement disclosure purposes experienced greater increases in their price-earnings multiples and earnings response coefficients than firms that had not used the fair value method for proxy statement purposes. 


\section{Sample Selection}

The purpose of this study is to examine the perceived earnings quality implications of the recognizing firms' announcements to voluntarily adopt the fair value method of accounting for stock-based compensation during the period between July and December 2002. A search of corporate press releases and business news articles on the Dow Jones News Services Database (now Factiva) results in a potential sample of 150 recognizing firms. As depicted in Figure 1, the majority of recognizing firms made announcements to voluntarily recognize stock-based compensation expense in July and August of 2002. Specifically, 30 firms made announcements in July, and 64 firms made announcements in August. The remaining 56 announcement dates occurred fairly evenly in the remaining period September through December 2002.

Because the focus of this study is on financial reporting issues under U.S. GAAP, nine foreign firms (18 firm-years) were excluded to avoid inconsistencies in financial reporting. An additional five firms (10 firm-years) were eliminated due to data unavailability resulting from the occurrence of mergers, restatements, or bankruptcy filings during the pre- and post-

announcement periods. Finally, we exclude three firms that changed yearends during the pre- or post-announcement periods. Including these firms would have resulted in using inconsistent earnings measures during our test period.

The resulting sample of 133 recognizing firms (266 firm-years) consists of 44 firms that implemented the fair value method beginning in fiscal 2002, 83 firms that planned to implement the fair value method starting in fiscal 2003, and six firms that postponed implementation until fiscal $2004 .^{7}$ Because we test the hypothesis that the recognizing firms' announcements to adopt the SFAS 123 recognition provisions, not the actual recognition of ESO expense in the income

\footnotetext{
${ }^{7}$ When we compare just the 2002 implementers to the control firms in the estimations of equations (3) and (6), our results fail to support both $\mathrm{H} 1$ and $\mathrm{H} 2$. This result could be due to low number of recognizing firm-years in our test samples.
} 
statement, signals higher earnings quality, we use income before changes in accounting principles as our earnings measure to ensure that recognized SFAS 123 ESO expense is excluded in the post-announcement period firm-years. Doing so makes post-announcement earnings for the 2002 implementers comparable to earnings for all other firm-years.

Our test samples are determined as follows. For purposes of the tests using the priceearnings multiple as a surrogate for earnings quality, 7 firm-years with missing data and 39 firmyears with losses were excluded, reducing the recognizing firm sub-sample from 266 to 220 firm-years. ${ }^{8}$ This subsample is further reduced to 205 firm-years when observations that result in a studentized residual greater than two in the estimation of equation (3) are deleted. When the earnings response coefficient is used as a proxy for earnings quality, 17 firm-years with missing data are eliminated, resulting in a recognizing firm sub-sample of 249 firm-years. Four firmyears that result in a studentized residual greater than two in the estimation of equation (6) are deleted, resulting in a sub-sample of 245 firm-years. ${ }^{9}$

Following ABK (2004a), we identify a control group consisting of all firms from the S\&P 500, S\&P 400 mid-capitalization, and S\&P 600 small-capitalization indices that did not announce plans to voluntarily adopt the SFAS 123 recognition provisions during 2002 and have data available on Compustat necessary to perform our tests. ${ }^{10}$ After deleting influential observations based on studentized residuals greater than two in the estimation of equations (3) and (6), respectively, this selection process results in control samples of 2,131 firm-years for our

\footnotetext{
${ }^{8}$ Firm years in which net losses are reported are eliminated from the sample because prior research (eg. Collins, Pincus, and Xie, 1999) shows that the relation between stock price and earnings is different for profitable versus loss firms, and that the stock price of the latter firms is driven by the book value of equity.

${ }^{9}$ Consistent with ABK (2004a), a substantial percentage of the recognizing firms are from the financial institutions industry (SIC one-digit code =6). Specifically, 109 firm-years (53 percent) and 120 firm-years (49 percent) in the price-earnings multiple and earnings response coefficient test samples, respectively, are from this industry. When we re-estimate equations (3) and (6) excluding these firms, our results fail to support either H1 or H2.

${ }^{10}$ ABK (2004a) also restrict their control group to firms that disclosed SFAS 123 in the footnotes and to industries matching at least one firm in the recognizing sample. We do not impose these restrictions..
} 
price-earnings multiple tests in which loss-year observations are excluded, and 2,582 firm-years for our earnings response coefficient tests in which loss-year observations are retained. ${ }^{11}$ This sample selection process is summarized in Table 1. All variables are winsorized at the extreme $1^{\text {st }}$ and $99^{\text {th }}$ percentiles.

\section{Results}

Table 2 reports descriptive statistics separately for the recognizing firm sub-sample $\left(D S_{i}=1\right)$ and the non-recognizing firm control group $\left(D S_{i}=0\right)$. The recognizing firm sub-sample means and medians for both earnings $\left(E_{i t}\right)$ and market value of equity $\left(M V E_{i t}\right)$ are significantly greater than the corresponding means and medians for the control group of firms. These results suggest that the recognizing firms, which are more profitable and larger than the control firms, have more ability to take the hit to earnings resulting from expensing ESOs. Interestingly, the debt to equity ratio, a proxy for debt covenant constraints, mean and median are significantly greater for the recognizing firm sub-sample than the corresponding mean and median for the control group of firms. There is no statistical difference in stock returns $\left(R_{i t}\right)$ or change in earnings $\left(\Delta E_{i t}\right)$ between the two groups.

Table 3 reports the results of testing $\mathrm{H} 1$ using the price-earnings multiple as a proxy for earnings quality. The first column in Table 3 reports the results of regressing the market value of equity on earnings, equation (1), for the recognizing firm sub-sample, resulting in a priceearnings multiple of 8.8129 (two-tailed $\mathrm{p}<0.001$ ). The second column of Table 3 reports the results of estimating equation (2) for the recognizing firm sub-sample. Consistent with H1, the coefficient on $E_{i t} * D P_{i}$ is positive (coefficient estimate $=0.8049$ ) and statistically significant (two-tailed $\mathrm{p}=0.089$ ). This result suggests that firms' announcements to adopt the fair value

\footnotetext{
${ }^{11}$ Our results are sensitive to the exclusion of influential observations. When we include these influential observations in our test samples, our results generally fail to support either $\mathrm{H} 1 \mathrm{or} \mathrm{H} 2$.
} 
method of accounting for stock-based compensation are associated with an increased priceearnings multiple in the post-announcement period, consistent with the hypothesis that announcements to recognize ESO expense signal higher earnings quality. The final column of Table 3 reports the results of estimating equation (3) for the full sample, which includes the control set of firm-years that did not announce plans in 2002 to recognize ESO expense using the fair value method. The coefficient on $E_{i t}{ }^{*} D P_{i}{ }^{*} D S_{i}$ is significantly greater than zero (coefficient estimate $=1.0908 ;$ two-tailed $\mathrm{p}=0.065)$, consistent with an increased price-earnings multiple for the recognizing firms relative to the control firms. This result helps rule out the alternative explanation that the increased price-earnings multiple for the recognizing firms is due to other events occurring during this time period.

Table 4 reports the results of testing $\mathrm{H} 1$ using the earnings response coefficient as the surrogate for earnings quality. The first column reports the results of estimating equation (4) for the recognizing firm sub-sample. The coefficient on earnings $\left(E_{i t}\right)$ is significantly positive (twotailed $\mathrm{p}<0.001)$, but the coefficient on the change in earnings $\left(\Delta E_{i t}\right)$ is insignificant (two-tailed $\mathrm{p}=0.212$ ). The second column of Table 4 reports the results of estimating equation (5) for the recognizing firm sub-sample. These results reflect a significantly positive incremental coefficient on $E_{i t}{ }^{*} D P_{i}$ (coefficient estimate $=0.6233$; two-tailed $\mathrm{p}=0.003$ ) but not $\Delta E_{i t}{ }^{*} D P_{i}$ (twotailed $\mathrm{p}=0.234)$. This latter result is not surprising given that the coefficient on $\Delta E_{i t}$ is insignificant in the across-year (column one) estimation. The last column of Table 4 reflects the results of estimating equation (6). In this estimation, the coefficient on $E_{i t}{ }^{*} D P_{i} * D S_{i}$ is insignificant (two-tailed $\mathrm{p}=0.651$ ), but the positive coefficient on $\Delta E_{i t}{ }^{*} D P_{i}{ }^{*} D S_{i}, 0.2747$, is significantly different from zero (two-tailed $\mathrm{p}=0.065$ ). The results indicate that after controlling for the pre- and post- announcement period effects, the recognizing firms (DS=1) have an 
incremental increase in value relevance of earnings changes but not earnings levels relative to the control firms (DS=0). Overall, the earnings response coefficient test results reported in Table 4 are consistent with the hypothesis that the recognizing firms had an increase in perceived earnings quality after the announcements to recognize ESO expense using the fair value method. Taken together, both the price-earnings multiple and earnings response coefficient test results are consistent with the hypothesis that the recognizing firms' announcements to adopt the SFAS 123 recognition provisions increased their perceived earnings quality.

We now turn our discussion to the test of our hypothesis $(\mathrm{H} 2)$ that recognizing firms that previously used the fair value method in their proxy statement ESO disclosures have a greater increase in earnings quality than the recognizing firms that use the potential realizable value method in their proxy statements. In the sample of recognizing firms, 61 , or $46 \%$, used a fair value method in their proxy statement ESO disclosures. The results of estimating equation (7) are reported in Table 5, Panel A. Inconsistent with $\mathrm{H} 2$, when using the price-earnings multiple as a proxy for earnings quality, the coefficient on $E_{i t}{ }^{*} D P_{i}{ }^{*} F V_{i}$ is insignificant (two-tailed $\mathrm{p}=0.770$ ). Likewise, as reported in Panel B of Table 5, when using the earnings response coefficient as the earnings quality surrogate, neither the coefficient on $E_{i t}{ }^{*} D P_{i}{ }^{*} F V_{i}$ nor $\Delta E_{i t}{ }^{*} D P_{i} * F V_{i}$ in the estimation of equation (8) is significantly differently from zero. Overall, the estimation results reported in Table 5 do not support $\mathrm{H} 2$; i.e., we provide no evidence consistent with the hypothesis that the recognizing firms that previously used the fair value method for proxy statement disclosure purposes had a greater increase in perceived earnings quality than those recognizing firms not using the fair value method for such purposes.

We next perform a sensitivity test based on the ABK (2004a) finding that only those firms that announced plans to voluntarily recognize ESO expense early (July, 2002 announcers) 
experienced significantly positive announcement period returns. To provide evidence on whether early announcers experience greater increases in earnings quality than late announcers, we modify equations (2) and (5) as follows:

$$
\begin{aligned}
M V E_{i t}= & \alpha_{0}+\alpha_{1} E_{i t}+\alpha_{2} D P_{i}+\alpha_{3} E_{i t}{ }^{*} D P_{i}+\alpha_{4} E A R L Y_{i}+\alpha_{5} E_{i t}{ }^{*} E A R L Y_{i} \\
& +\alpha_{6} D P_{i t}{ }^{*} E A R L Y_{i}+\alpha_{7} E_{i t}{ }^{*} D P_{i} * E A R L Y_{i}+\varepsilon_{i t} \\
R_{i t}=\beta_{0} & +\beta_{1} E_{i t}+\beta_{2} \Delta E_{i t}+\beta_{3} D P_{i}+\beta_{4} E_{i t} * D P_{i}+\beta_{5} \Delta E_{i t} * D P_{i}+\beta_{6}{ }^{*} E A R L Y_{i} \\
& +\beta_{7} E_{i t}{ }^{*} E A R L Y_{i}+\beta_{8} \Delta E_{i t}{ }^{*} E A R L Y_{i}+\beta_{9} D P_{i} * E A R L Y_{i}+\beta_{10} E_{i t} * D P_{i} * E A R L Y_{i} \\
& +\beta_{11} \Delta E_{i t}{ }^{*} D P_{i}{ }^{*} E A R L Y_{i}+\mu_{\mathrm{it}}
\end{aligned}
$$

where

$E A R L Y_{i}=$ an indicator variable equal to 1 if the firm announced the switch to recognize ESO expense in July of 2002; EARLY $_{i}$ equals 0 if the firm announced the switch after July 31, 2002 and on or before December 31, 2002; and all other variables are as previously defined.

The results of estimating equation (9) are reported in Table 6, Panel A. The coefficient on $E_{i t}{ }^{*} D P_{i}{ }^{*} E A R L Y_{i}$ is not significantly different from zero (two-tailed $\left.\mathrm{p}=0.999\right)$. Panel $\mathrm{B}$ of Table 6 reports the results of estimating equation (10). Also inconsistent with the early announcers having a greater increase in earning quality than subsequent announcers, the coefficients on $E_{i t}{ }^{*} D P_{i}{ }^{*} E A R L Y_{i}$ and $E_{t}{ }^{*} D P_{i}{ }^{*} E A R L Y_{i}$ are not significantly different from zero (two-tailed $\mathrm{p}=0.127$ and 0.642 , respectively). Overall, the results reported in Table 6 provide no evidence that the early announcers experienced a greater increase in perceived earnings quality than the late announcers. 


\section{Conclusion}

Based on a sample of 133 firms that announced plans to voluntarily adopt the fair value method of accounting for stock-based compensation between July and December 2002, this study provides evidence that these recognizing firms experienced a significantly greater priceearnings multiple and earnings response coefficient in the post-announcement date period. This study provides no evidence, however, that the recognizing firms using the fair value method in their proxy statements experienced significantly greater increases in perceived earnings quality in the post-announcement period than the firms using the potential realizable value method.

Our results provide evidence consistent with the recognizing firms' announcements to voluntarily recognize SFAS 123 ESO expense, an accounting choice that is conservative because it results in the persistent understatement of net income relative to footnote disclosure, sending a credible signal of earnings quality to market participants. This evidence thus contributes to the voluntary accounting choice (e.g., Fields, Lys and Vincent, 2001) and conservatism (e.g., Ahmed et al., 2002) streams of literature. Also, because the signal of earnings quality sent to market participants involves recognizing an expense already disclosed in the footnotes, our evidence adds to the literature addressing recognition versus disclosure (e.g., Bernard and Schipper, 1994; Aboody 1997; Barth, Clinch and Shibano, 2003; ABK, 2004b). Finally, because our evidence suggests that market participants perceive that firms expensing ESOs have higher earnings quality, this evidence implies that investors prefer expensing of ESOs to footnote disclosure. We

thus contribute to the ongoing debate concerning accounting for stock-based compensation (e.g., Dechow, Hutton and Sloan, 1996; Espahbodi et al., 2002; ABK, 2004a; ABK, 2004b). 


\section{References}

Accounting Principles Board (APB). 1973. Accounting for stock issued to employees. APB Opinion No. 25. New York: APB.

Aboody D. 1997. Recognition versus disclosure in the oil and gas industry. Journal of Accounting Research Supplement: 21-32.

Aboody D., M. Barth, R. Kasznik. 2004a. Firms' voluntary recognition of stock-based compensation expense. Journal of Accounting Research 42: 123-150. . 2004b. SFAS 123 Stock-based compensation expense and equity market values. The Accounting Review 79: 251-275.

Ahmed, A., B. Billing, R. Morton, and M. Stanford-Harris. 2002. The role of accounting conservatism in mitigating bondholder-shareholder conflicts over dividend policy and in reducing debt costs. The Accounting Review 77: 867-890.

Bagnoli, M. and S. Watts. 2004. Conservative accounting choices. Working paper, Purdue University.

Barth, M., G. Clinch, and T. Shibano. 2003. Market effects of recognition and disclosure. Journal of Accounting Research 41: 581-609.

Bartov, E. and G. M. Bodnar. 1996. Alternative accounting methods, information asymmetry and liquidity: Theory and evidence. The Accounting Review 71: 397-418.

Becker, G. 2002. Options are Useful- but only if they're used right. Business Week (August 5): 26.

Bernard V., and K. Schipper.1994. Recognition and disclosure in financial reporting. Working Paper, University of Michigan and University of Chicago.

Buffett, W. (2002, April 9). Stock options and common sense. The Washington Post: A19.

Collins, D., M. Pincus, and H. Xie. 1999. Equity valuation and negative earnings. The Accounting Review 74 (1): 29-61.

Dechow, P., A. Hutton, and R. Sloan. 1996. Economic consequences of accounting for stockbased compensation. Journal of Accounting Research 34: 1-20.

Easton, P., and T. Harris. 1991. Earnings as an explanatory variable for returns. Journal of Accounting Research 29: 19-36. 
Espahbodi, H., P. Espahbodi, Z. Rezaee, and H. Tehranian. 2002. Stock price reaction and value relevance of recognition versus disclosure: The case of stock-based compensation. Journal of Accounting and Economics 33: 343-373.

Fields, T., T. Lys,and L. Vincent. 2001. Empirical research on accounting choice. Journal of Accounting and Economics 31: 255-307.

Financial Accounting Standards Board (FASB). 1993. Accounting for stock-based compensation, Exposure draft. Norwalk, CT: FASB. . 1995 Accounting for stock-based compensation. FASB Statement No. 123, Norwalk, CT: FASB. . 2004. Proposed statement on share based payments. Norwalk, CT: FASB.

Ghosh, A. and D. Moon. 2005. Auditor tenure and perceptions of audit quality. The Accounting Review 80, forthcoming.

Greenspan, A. (2002, May 3). Stock options and related matters. [Speech] 2002 Financial Markets Conference of the Federal Reserve Bank of Atlanta, Sea Island Georgia. Retrieved June 18, 2003, from http://www.federalreserve.gov/boarddocs/speeches/2002/20020503/default.htm

Henry, D. (2002, July 29). Expect surprises long after August 14. Business Week, 33-46.

Hughes, J., and C. Levine. 2003. Management compensation and earnings-based covenants in resolving adverse selection in credit markets. Journal of Applied Corporate Finance, forthcoming

International Accounting Standards Board (IASB). 2004. Shared based payments.

Morgenson, G., J. Glater. (2003, February 14). Ernst \& Young changes mind on options. The New York Times. Retrieved February 17, 2003, from http://www.nytimes.com/2003/0214/business/14OPTI.html

Schipper, K., and L. Vincent. 2003. Earnings quality. Accounting Horizons 17 Supplement: 97 110.

United States House of Representatives. 108th Congress, 1st Session. H.R. 3574, Stock Option Accounting Reform Act. Retrieved March 22, 2004 from http://thomas.loc.gov

Vickers, M. (2002, July 29). The good news in all that bad news. Business Week, 33-46. 


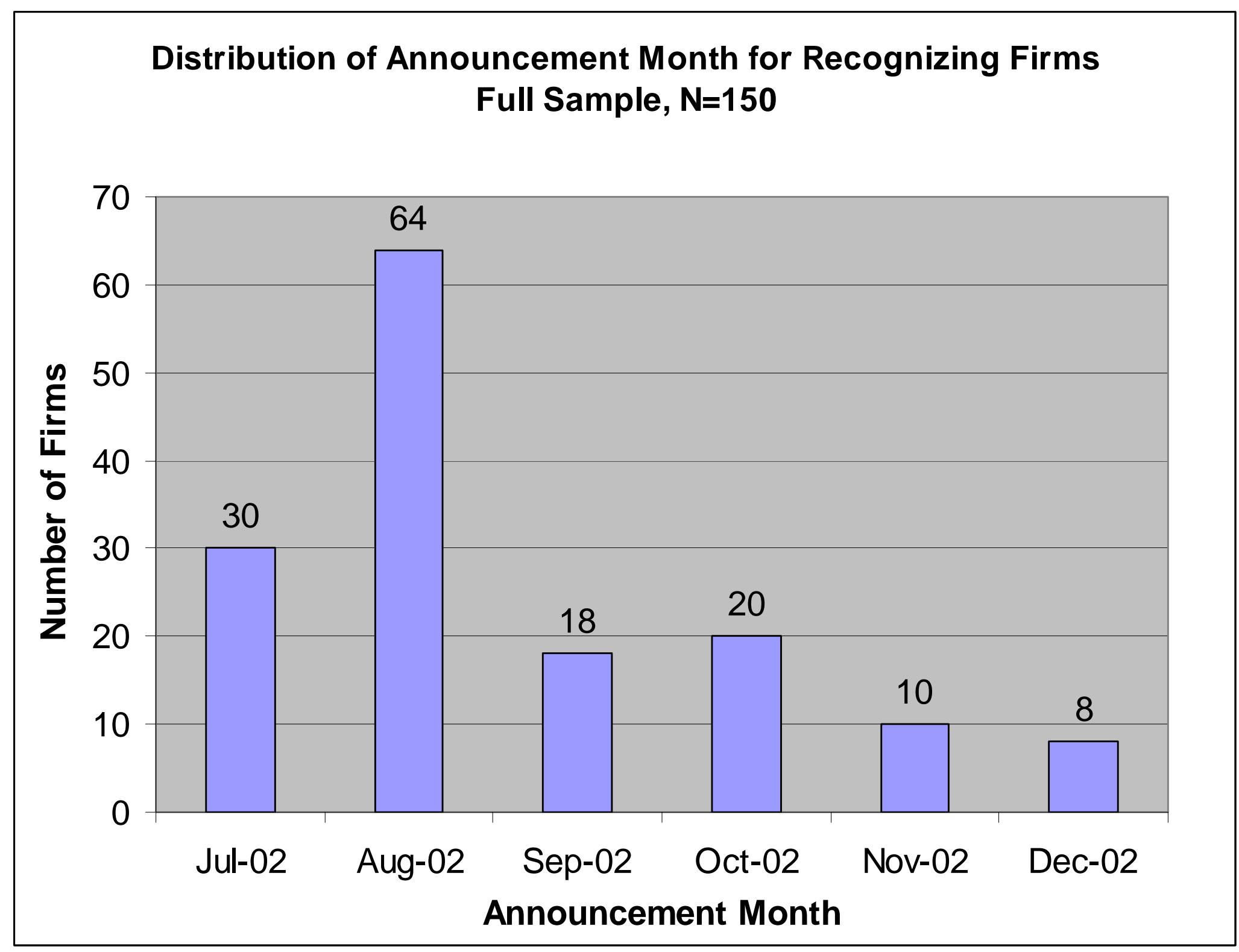

Adapted from Aboody, Barth, and Kasznik (2004a) 
Total firms

Less: Foreign firms

Less: Firms with no data available

Less: Firms with change in year end

Firms in sample

Firm-years (pre- and post-

announcement years)

Less: Firm-years with missing data

Less: Firm-years with losses

Less: Influential observations ${ }^{3}$

Final sample
Table 1

Sample Selection

\section{Earnings Quality Measure}

\begin{tabular}{|c|c|c|c|}
\hline \multicolumn{2}{|c|}{$\begin{array}{l}\text { Price-earnings } \\
\text { Multiple }\end{array}$} & \multicolumn{2}{|c|}{$\begin{array}{c}\text { Earnings Response } \\
\text { Coefficient }\end{array}$} \\
\hline Recognizing & Control & Recognizing & Control \\
\hline Firms $^{1}$ & Firms $^{2}$ & Firms $^{1}$ & Firms $^{2}$ \\
\hline 150 & 1,411 & 150 & 1,411 \\
\hline (9) & ---- & (9) & ---- \\
\hline (5) & ---- & (5) & ---- \\
\hline (3) & (9) & (3) & (9) \\
\hline 133 & $1, \overline{402}$ & 133 & 1,402 \\
\hline 266 & 2,804 & 266 & 2,804 \\
\hline (7) & (32) & (17) & (89) \\
\hline (39) & (516) & ---' & --- \\
\hline (15) & (125) & (4) & (133) \\
\hline 205 & 2,131 & 245 & 2,582 \\
\hline
\end{tabular}

${ }^{1}$ Recognizing firms are those firms that announced plans to voluntarily adopt the fair value method of accounting for stock-based compensation during the period between July and December, 2002 ${ }^{2}$ Control firms consist of all firms from the S\&P 500, S\&P 400 mid-capitalization, and S\&P 600 small-capitalization indices that did not announce plans to voluntarily adopt the SFAS 123 recognition provisions during 2002.

${ }^{3}$ Influential observations are defined as those observations with a studentized residual greater than two in the estimation of equation (3) for the price-earnings multiple tests and equation (6) for the earnings response coefficient tests. 
Table 2

Descriptive Statistics

\begin{tabular}{|c|c|c|c|c|c|c|c|c|}
\hline & \multirow[b]{2}{*}{$\mathrm{N}$} & \multirow[b]{2}{*}{ Mean } & \multirow[b]{2}{*}{$\begin{array}{l}\text { Standard } \\
\text { Deviation }\end{array}$} & \multirow[b]{2}{*}{ Minimum } & \multicolumn{3}{|c|}{ Percentiles } & \multirow[b]{2}{*}{ Maximum } \\
\hline & & & & & $25^{\text {th }}$ & 50th & 75 th & \\
\hline \multicolumn{9}{|c|}{$D S=1-$ Recognizing firms } \\
\hline$M V E$ & 205 & $35.0246^{*}$ & 15.8046 & 5.0475 & 25.4135 & $33.7112 *$ & 42.0179 & 85.9653 \\
\hline$R$ & 245 & -0.0360 & 0.2631 & -0.7265 & -0.2208 & -0.0586 & 0.1185 & 0.6460 \\
\hline$\Delta E$ & 245 & 0.0013 & 0.0864 & -0.2807 & -0.0237 & 0.0037 & 0.0268 & 0.4397 \\
\hline$R S B C E$ & 37 & 14.5857 & 60.0992 & 0.0120 & 0.0910 & 0.4050 & 3.3000 & 365.0000 \\
\hline \multicolumn{9}{|c|}{$D S=0-$ Control firms } \\
\hline$E$ & 2,131 & $1.4347^{*}$ & 1.0393 & 0.0541 & 0.7347 & $1.2340 *$ & 1.8692 & 6.2697 \\
\hline$M V E$ & 2,131 & $26.3043 *$ & 12.4899 & 5.0475 & 17.3505 & $24.6523 *$ & 33.5535 & 85.9653 \\
\hline$R$ & 2,582 & -0.0742 & 0.2797 & -0.7265 & -0.2580 & -0.0828 & 0.1139 & 0.7793 \\
\hline
\end{tabular}

\section{Notes to Table 2}

$D S$ is an indicator variable $=1$ if the firm is a recognizing firm and $=0$ if the firm is a control firm.

$E$ is income before extraordinary items, discontinued operations, and changes in accounting principles (annual Compustat data item $I B$ ) scaled by the common shares outstanding (annual Compustat data item $\mathrm{CSHO}$ ) as of the beginning of the fiscal year.

$M V E$ is the market value of equity three months after fiscal year end (monthly Compustat data item MKVALM) scaled by the common shares outstanding (annual Compustat data item $\mathrm{CSHO}$ ) as of the beginning of the fiscal year.

$R$ is the market adjusted cumulative return for the twelve month period ending three months after fiscal year end.

$\triangle E$ is the change in income before extraordinary items, discontinued operations, and changes in accounting principles from year t-1 (annual Compustat data item $I B$ ) scaled by market value of equity at the end of the third month after year t-2 fiscal year end (monthly Compustat data item MKVALM).

Debt/Equity Total long term debt (Compustat data item DLTT) divided by common equity (Compustat data item CEQ) at the end of year t.

$D S B C E$ stock based compensation expense disclosed in the financial statements of the recognizing firms in millions of dollars.

$R S B C E$ stock based compensation expense recognized in the financial statements of post-announcement period implementers in millions of dollars.

$E, M V E, R$, and $\Delta E$ are all winsorized at the extreme $1 \%$ and $99 \%$. Observations that have studentized residuals $>2$ in estimating equations (3) or (6) are deleted.

* Mean or median is significantly different across the two groups at a two-tailed $p<0.001$. 
Table 3

Effect of Announcing the Adoption of the Fair Value Method of Accounting for Stock Options on the Price-earnings Multiple

Dependent variable is the Scaled Market Value of Equity (MVE)

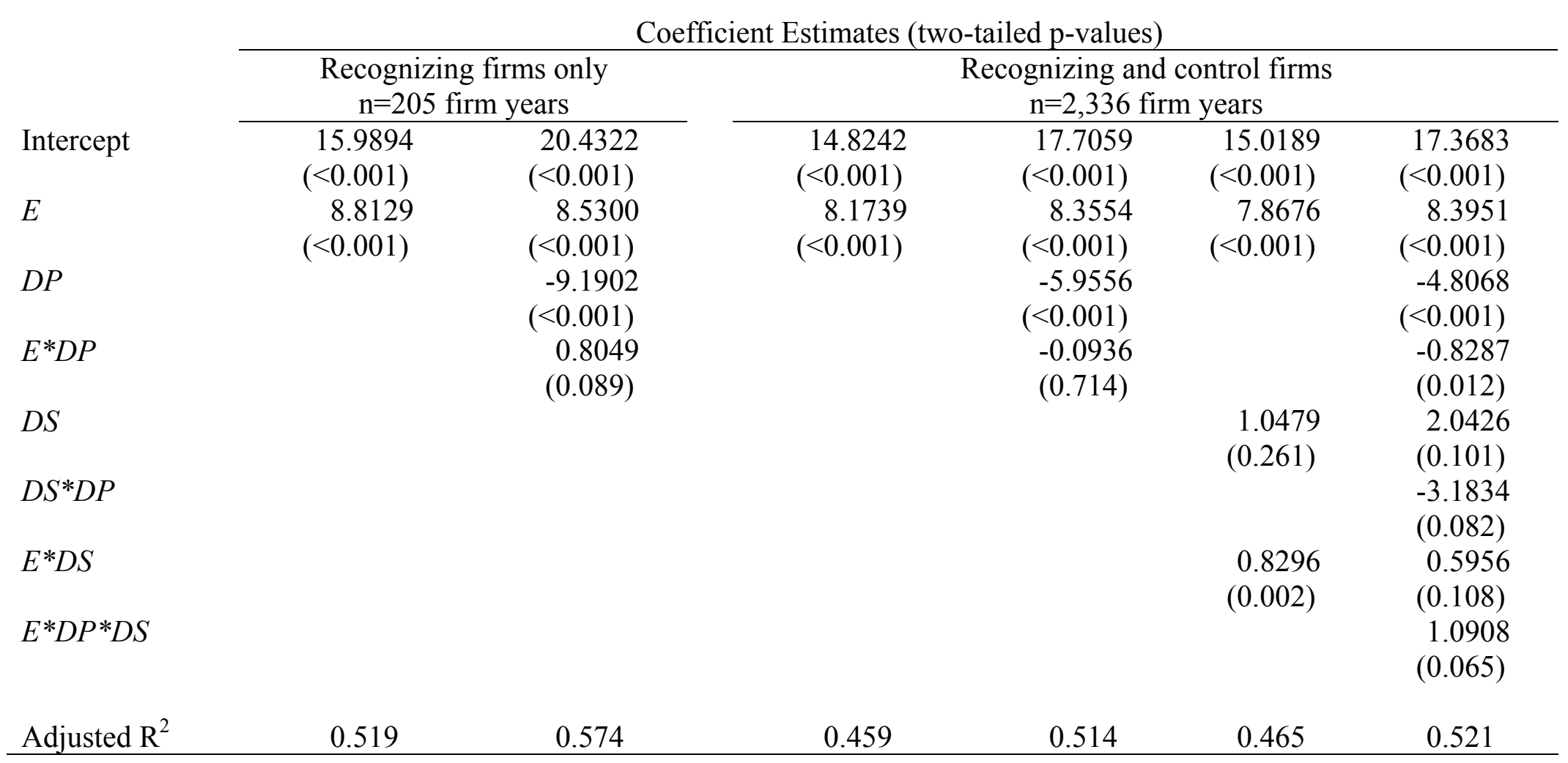




\section{Notes to Table 3}

$M V E$ is the market value of equity three months after fiscal year end (monthly Compustat data item MKVALM).

$E$ is income before extraordinary items, discontinued operations, and changes in accounting principles (annual Compustat data item $I B$ ).

$D P$ is an indicator variable $=1$ for the first fiscal year ending after the announcement to recognize SFAS 123 expense (June 2002) and $=0$ for the last fiscal year ending before the announcement (July 2002) for the recognizing (control) firms.

$D S$ is an indicator variable $=1$ if the firm is a recognizing firm and $=0$ if the firm is a control firm.

All variables, except the indicator variables, are scaled by the common shares outstanding (annual Compustat data item CSHO) as of the beginning of the fiscal year.

$E$ and $M V E$ are winsorized at the extreme $1 \%$ and $99 \%$. Observations with studentized residuals $>2$ from estimating equation (3) are deleted. 
Table 4

Effect of Announcing the Adoption of the Fair Value Method of Accounting for Stock Options on the Earnings Response Coefficient






\section{Notes to Table 4}

$R$ is the market adjusted cumulative return for the twelve month period ending three months after fiscal year end.

$E$ is income before extraordinary items, discontinued operations, and changes in accounting principles (annual Compustat data item $I B$ ) scaled by market value of equity at the end of the third month after year t-1 fiscal year end (monthly Compustat data item MKVALM).

$\triangle E$ is the change in income before extraordinary items, discontinued operations, and changes in accounting principles from year t-1 (annual Compustat data item $I B$ ) scaled by market value of equity at the end of the third month after year t-2 fiscal year end (monthly Compustat data item MKVALM).

$D P$ is an indicator variable $=1$ for the first fiscal year ending after the announcement to recognize SFAS 123 expense (June 2002 ) and $=0$ for the last fiscal year ending before the announcement (July 2002) for the recognizing (control) firms.

$D S$ is an indicator variable $=1$ if the firm is a recognizing firm and $=0$ if the firm is a control firm.

$R, E$, and $\Delta E$ are winsorized at the extreme $1 \%$ and $99 \%$. Observations with studentized residuals $>2$ from estimating equation (6) are deleted. 
Table 5

Incremental Effect of Consistency in Stock Option Value Disclosures

Panel A - Price-earnings Multiple - Dependent Variable is MVE

$\begin{array}{lcc} & \text { Coefficient Estimate } & \text { Two-tailed p-value } \\ \text { Intercept } & 19.7528 & <0.001 \\ E & 7.6003 & <0.001 \\ D P & -7.2706 & 0.002 \\ E^{*} D P & 0.8310 & 0.120 \\ F V & 2.7947 & 0.437 \\ F V^{*} D P & -3.7395 & 0.407 \\ E^{*} F V & 1.4617 & 0.312 \\ E^{*} D P^{*} F V & -0.4518 & 0.770 \\ \text { Adjusted } \mathrm{R}^{2} & & \\ \mathrm{~N} & 0.586 & \end{array}$

\section{Notes to Table 5 Panel A}

MVE is the market value of equity three months after fiscal year end (monthly Compustat data item MKVALM). $E$ is income before extraordinary items, discontinued operations, and changes in accounting principles (annual Compustat data item $I B$ ).

$D P$ is an indicator variable $=1$ for the first fiscal year ending after the announcement to recognize SFAS 123 expense (June 2002) and $=0$ for the last fiscal year ending before the announcement (July 2002) for the recognizing (control) firms.

$F V$ is an indicator variable $=1$ if the company previously used a fair value option pricing model in its proxy statement (Black Scholes or binomial method). $F V=0$ if the company used an alternate option pricing model in its proxy statement (Potential Realizable Value method).

All variables, except the indicator variables, are scaled by the common shares outstanding (annual Compustat data item $(\mathrm{CSHO}$ ) as of the beginning of the fiscal year.

$E$ and $M V E$ are winsorized at the extreme $1 \%$ and $99 \%$. Observations with studentized residuals $>2$ from estimating equation (3) are deleted. 
Table 5 (Continued)

Panel B - Earnings Response Coefficient - Dependent Variable is R

\begin{tabular}{lcc} 
& Coefficient Estimate & Two-tailed p-value \\
\cline { 2 - 3 } Intercept & -0.0755 & 0.029 \\
$E$ & 0.6385 & 0.051 \\
$\Delta E$ & 0.5961 & 0.147 \\
$D P$ & 0.0297 & 0.487 \\
$E^{*} D P$ & 0.7958 & 0.003 \\
$\Delta E^{*} D P$ & -0.0451 & 0.848 \\
$F V$ & -0.1544 & 0.003 \\
$F V^{*} D P$ & 0.1631 & 0.015 \\
$E^{*} F V$ & 1.1527 & 0.057 \\
$\Delta E^{*} F V$ & -0.8994 & 0.023 \\
$E^{*} D P^{*} F V$ & -1.0827 & 0.130 \\
$\Delta E^{*} D P^{*} F V$ & -0.1184 & 0.883 \\
& & \\
Adjusted $\mathrm{R}^{2}$ & 0.307 & \\
$\mathrm{~N}$ & 241 & \\
\end{tabular}

\section{Notes to Table 5 Panel B}

$R$ is the market adjusted cumulative return for the twelve month period ending three months after fiscal year end. $E$ is income before extraordinary items, discontinued operations, and changes in accounting principles (annual Compustat data item $I B$ ) scaled by market value of equity at the end of the third month after year $\mathrm{t}-1$ fiscal year end (monthly Compustat data item MKVALM).

$\Delta E$ is the change in income before extraordinary items, discontinued operations, and changes in accounting principles from year t-1 (annual Compustat data item $I B$ ) scaled by market value of equity at the end of the third month after year t-2 fiscal year end (monthly Compustat data item MKVALM).

$D P$ is an indicator variable $=1$ for the first fiscal year ending after the announcement to recognize SFAS 123 expense (June 2002) and $=0$ for the last fiscal year ending before the announcement (July 2002) for the recognizing (control) firms.

$F V$ is an indicator variable $=1$ if the company previously used a fair value option pricing model in its proxy statement (Black Scholes or binomial method). $F V=0$ if the company used an alternate option pricing model in its proxy statement (Potential Realizable Value method).

$R, E$ and $\Delta E$ are winsorized at the extreme $1 \%$ and $99 \%$. Observations with studentized residuals $>2$ from estimating equation (6) are deleted. 
Table 6

Incremental Effect of Early versus Late Announcers

\section{Panel A - Price-earnings Multiple - Dependent Variable is MVE}

Intercept
$E$
$D P$
$E^{*} D P$
$E A R L Y$
$E A R L Y * D P$
$E^{*} E A R L Y$
$E^{*} D P^{*} E A R L Y$

Adjusted $\mathrm{R}^{2}$

$\mathrm{N}$ $\underline{\text { Coefficient Estimate }}$

20.4309

8.3667

$-8.0579$

0.6248

0.0250

$-2.9084$

0.4633

$-0.0015$

0.570

205

\author{
Two-tailed p-value \\ $<0.001$ \\ $<0.001$ \\ 0.001 \\ 0.441 \\ 0.993 \\ 0.525 \\ 0.358 \\ 0.999
}

\section{Notes to Table 6 Panel A}

$M V E$ is the market value of equity three months after fiscal year end (monthly Compustat data item MKVALM). $E$ is income before extraordinary items, discontinued operations, and changes in accounting principles (annual Compustat data item $I B$ ).

$D P$ is an indicator variable $=1$ for the first fiscal year ending after the announcement to recognize SFAS 123 expense (June 2002) and $=0$ for the last fiscal year ending before the announcement (July 2002) for the recognizing (control) firms.

$E A R L Y$ is an indicator variable $=1$ if the company announced the switch in July of 2002. EARLY $=0$ if the company announced the switch after July 31, 2002 and before December 31, 2002.

All variables, except the indicator variables, are scaled by the common shares outstanding (annual Compustat data item $\mathrm{CSHO}$ ) as of the beginning of the fiscal year.

$E$ and $M V E$ are winsorized at the extreme $1 \%$ and $99 \%$. Observations with studentized residuals $>2$ from estimating equation (3) are deleted. 
Table 6 (Continued)

Panel B - Earnings Response Coefficient - Dependent Variable is R

Intercept
$E$
$\Delta E$
$D P$
$E^{*} D P$
$\Delta E^{*} D P$
$E A R L Y$
$E A R L Y^{*} D P$
$E^{*} E A R L Y$
$\triangle E^{*} E A R L Y$
$E^{*} D P^{*} E A R L Y$
$\triangle E^{*} D P^{*} E A R L Y$

Adjusted $\mathrm{R}^{2}$

$\mathrm{N}$

\section{Coefficient Estimate}

$-0.1701$

1.4124

$-0.3643$

0.0866

0.5211

0.3132

0.0530

0.2592

$-1.3259$

1.2237

$-1.8618$

$-0.6596$

0.324 \begin{tabular}{c} 
Two-tailed p-value \\
\hline$<0.001$ \\
$<0.001$ \\
0.202 \\
0.012 \\
0.014 \\
0.065 \\
0.385 \\
0.018 \\
0.034 \\
0.301 \\
0.127 \\
0.642
\end{tabular}

245

\section{Notes to Table 6 Panel B}

$R$ is the market adjusted cumulative return for the twelve month period ending three months after fiscal year end. $E$ is income before extraordinary items, discontinued operations, and changes in accounting principles (annual Compustat data item $I B$ ) scaled by market value of equity at the end of the third month after year $\mathrm{t}-1$ fiscal year end (monthly Compustat data item MKVALM).

$\Delta E$ is the change in income before extraordinary items, discontinued operations, and changes in accounting principles from year t-1 (annual Compustat data item $I B$ ) scaled by market value of equity at the end of the third month after year t-2 fiscal year end (monthly Compustat data item MKVALM).

$D P$ is an indicator variable $=1$ for the first fiscal year ending after the announcement to recognize SFAS 123 expense (June 2002) and $=0$ for the last fiscal year ending before the announcement (July 2002) for the recognizing (control) firms.

$E A R L Y$ is an indicator variable $=1$ if the company announced the switch in July of 2002. EARLY $=0$ if the company announced the switch after July 31, 2002 and before December 31, 2002.

$R, E$ and $\Delta E$ are winsorized at the extreme $1 \%$ and $99 \%$. Observations with studentized residuals $>2$ from estimating equation (6) are deleted. 